\title{
Efficiency and Productivity of Textile Industry Sub-sector with Total Factor Productivity Approaches
}

\author{
Lies Maria Hamzah \\ Faculty of Economic and Business \\ University of Lampung \\ Bandar Lampung, Lampung \\ Indonesia
}

Received: March 27, 2021. Revised: April 7, 2021. Accepted: April 9, 2021. Published: April 16, 2021.

\begin{abstract}
The development of the manufacturing industry in Indonesia becomes a top priority because the manufacturing industry is a leading sector that can encourage other sectors and has forward and backward linkage between sectors.The difference in the use of technologythat still relatively low compared to the productivity of capital and labor will lead to differences in efficiency and productivity of each manufacturing industry sub-sector. The textile industry sub-sector contributes high amount to GDP and continues to increase every year. Total factor productivity (TFP) is considered a very comprehensive measure of productivity and efficiency.This measure explains the changes in production caused by changes in the amount of inputs used, changes in technology, capacity utilization and the quality of production factors. This study aims to analyze the effect of capital, labor, raw materials and energy to the output of the textile industry and textile products (TPT) (KBLI 14.15) with the Solow residual TFP approach. Another aim is to look at the efficiency and productivity of the textile industry sub-sector.The research used panel data regression with OLS model. The results of TFP estimation and TPT industry efficiency are different between TPT sub-sectors. TPT has integrity between downstream industries and upstream industries. Some of the obstacles in the textile industry in Indonesia include the high dependence of the Indonesian industry (TPT) on imported raw fiber materials $(90 \%)$. Most of the
\end{abstract}

age of the machines used by the TPT industry was old, this affects the TFP value.

Key-words: efficiency, manufacturing industry, productivity, textile industry, textile products, TFP

\section{INTRODUCTION}

The manufacturing industry sector is the driving force of other sectors, for that it must be able to produce output with the production process efficiently to maintain the sustainability of the industry. Efficiency in production is achieved if the available resources can be allocated effectively and efficiently (Porter, 2000 ).The contribution of the manufacturing industry sector to GDP in Indonesia is very large compared to other sectors. The contribution of the manufacturing industry sector to Indonesia's GDP is about 25 percent on average. This makes the manufacturing industry a leading sector for other sectors.

Increased production of large and medium manufacturing industries (IBS) in the first quarter of 2019 rose 4.45 percent compared to the same period last year. The increase in IBS production was supported by the production of the apparel industry sector which rose to 29.19 percent, this increase was due to abundant demand, especially from the export market. Textile industry and textile product (TPT) has the highest growth to 18,98 percent. (Central Bureau of Statistics)

The TPT industry in Indonesia is categorized into 3 industry groups as follows: 
1. Upstream industry, such as natural fiber and synthetic fiber industry

2. Intermediate industries, such as spinning, weaving, knitting and dying industries.

3. Downstream industry, such as garment industry (apparel) and other textile products

Upstream industries are generally capitalintensive industries, intermediate industries are semi-capital intensive industries but require a larger amount of labour than upstream industries.

Whiledownstream industry is a labor-intensive industry. The absorption of the TPT industry labor is in the apparel industry about $13.69 \%$ and the textile industry about $7.46 \%$ of the industrial labour in Indonesia in 2018. (Ministry of Industry, 2010).

Problems relating to the manufacturing industry sector in Indonesia include differences in the level of efficiency and productivity of the manufacturing industry sub-sector in Indonesia. The problem is due to inequality in the use of technology that is still relatively low compared to the productivity of capital and labor.

Related to the issue of inputs used efficiency, the manufacturing industry sector in Indonesia is a sector that is not yet efficient. The TPT industry sub-sector has a contribution to GDP and absorbs high amount oflabour. Indonesian TPT Industry Structure technically and structurally divided into three industrial sectors that are complete, vertical and integrated from upstream to downstream which have different characteristics in the use of technology and resources.

Utilization of the potential and technology possessed by the textile industry sub-sector can be observed at the level of productivity (efficiency level) of the textile industry sub-sector in Indonesia. The increase of efficiency is a major contributor to the productivity growth of the manufacturing industry in Indonesia.

Total factor productivity (TFP) is considered a very comprehensive measure of productivity and efficiency. This measure explains the changes in production caused by changes in the number of inputs used, changes in technology, capacity utilization and the quality of production factors.Jorgenson and Griliches (1967) and Hulten (2000) argue that TFP measures the "externalities" associated with technological advances that occur. Measurement of TFP growth can better reflect changes in output over time that cannot be explained in changes in the input combination used in the process production (Khan, 2006: 8).

Total factor productivity (TFP) is the level of transformation of total input to total output. TFP can be defined as the level of transformation of total input to total output. Thus the output ratio that results from the inputs used in the $t$ period is the size of the TFP in the t period (Diewert, 2002).

TFP measures the residual growth in total output of a company or the national economy that cannot be explained by the accumulation of input factor production productivity. The increase in TFP reflects the use of more efficient inputs, and TFP is often used as a measure of long-term technological change or dynamism caused by factors such as technical innovation. TFP cannot be measured directly. Conversely, TFP is a residue that contributes to the effect on total output that is not caused by input. In the Cobb-Douglas production function, TFP is captured by variable A.

(Diewert, 2002) Hulten (2001) argues that the residual Solow contribution is developed from the relationship of production functions and the index number approach. Solow uses the production function and limits on the productivity index.

This form of production function explains that the $A_{t}$ Index is more commonly used as TFP indicator. The level of growth of residual Solow outputs that is not explained by input growth includes several components (such as technical effects and organizational innovation).The residual TFP measures the costless benefits to society from innovations that are associated with externality parameters. By considering several alternative production functions based on Technical Progress (TP) and Returns to Scale (RS), TFP growth is an effect of both technical progress (shift in production function) and return of movement to non-constant production function scale (Diewert, 2001).

This study aims to analyze the efficiency of production inputs usedand productivity of the TPT industryin Indonesia from 2008 to 2014 by using the TFP residual Solow.

\section{RESEARCH METHOD}

The data used in this study uses the data of TPT industry companies in Indonesia. The data is the raw data from BPS large and medium industry surveys from 2008 to 2014. Furthermore, the data used are only companies that have complete data in the study period, as many as 40 types of companies.

The unit of analysis used in this study is the performance of the TPTcompanies by using the added value of the production of TPT companies and industry input of capital, labor, raw materials and energy used by TPT companies. Efficiency is one of the parameters that base on the performance 
of an Economic Unit Activity (UKE) and a component of the TFP measure.

The adjusted data is then processed and analyzed both quantitatively and qualitatively. This study will estimate using the Cobb-Douglas model with the Solow residual method approach by decomposing the source of output growth into input growth and changes in TFP $\left(\beta_{0}\right)$.

Data for $\beta_{0}$ variable cannot be directly observed so to know the value of $\beta_{0}$ variables, it can be obtained by first doing a regression without entering the $\beta_{0}$ variable into the equation. Estimates using the equation in log form are:

$y_{i t}=\beta_{l} l_{i t}+\beta_{k} k_{i t}+\beta_{m} m_{i t}+\beta_{e} e_{i t}++\varepsilon_{i t}$

Explanation:

$y_{i t} \quad=\log$ for value of companyoutputTPT $\mathrm{i}$ year $\mathrm{t}$ (in rupiah)

$l_{i t} \quad=\log$ fortotal of company labour TPT $\mathrm{i}$ year $\mathrm{t}$ (in person)

$k_{i t} \quad=\log$ for total of company capital TPT $\mathrm{i}$ year $\mathrm{t}$ (in rupiah)

$m_{i t} \quad=\log$ for total ofcompany raw materials TPT i year $\mathrm{t}$ (inpercentage)

$e_{i t} \quad=\log$ for total of company energy used TPT i year $\mathrm{t}$

$\varepsilon_{i t} \quad=$ error term

$\varepsilon_{i t}=\omega_{i t}+\eta_{i t}$

Explanation:

$\varepsilon_{i t} \quad=$ error term

$\omega_{i t} \quad=$ white noise component

$\eta_{i t} \quad=$ time shock to productivity.

The coefficient value obtained from the estimation results of equation (3) will be used to calculate the amount of TFP growth. The equation that will be used for estimating TFP is

$t f p_{i t}=y_{i t}-\hat{\beta}_{0}-\hat{\beta}_{l} l_{i t}-\hat{\beta}_{k} k_{i t}-\hat{\beta}_{m} m_{i t}-\beta_{e} e_{i t}$

$$
\begin{aligned}
& \text { Explanation } \\
& \begin{array}{ll}
t f p_{i t} & =\text { total of company production factor } \\
& \text { TPTi year } \mathrm{t} \\
y_{i t} \quad & =\text { value of company output TPT i year } \mathrm{t} \\
& \text { (in rupiah) }
\end{array}
\end{aligned}
$$

$l_{i t} \quad=$ total ofcompany labour TPTi year $\mathrm{t}$ (in person)

$k_{i t}=$ total of company capital TPT i year $\mathrm{t}$ (in rupiah)

$m_{i t} \quad=$ total of company raw material TPTi year $\mathrm{t}$ (in percentage)

$e_{i t} \quad=$ total of company energy used TPT i year $\mathrm{t}$

$\beta_{0} \quad=$ constanta

$\beta_{\mathrm{l}}, \beta_{\mathrm{k},}, \beta_{\mathrm{m}}, \beta_{\mathrm{e}}, \beta_{\mathrm{pma}}=$ parameter oflabour, capital, dan energy productivity.

Log TFP is a function of labor, capital and energy used in industry production process.

The steps taken use the data validity testing approach with the panel data unit root test. The unit root test used in this study is based on several statistic tests such ason level and on first difference. Next, the selection of the best model and Model Specification Test (F Test and T Test)

\section{RESULT AND DISCUSSION}

High productivity and efficiency in a UKE activity was needed. This condition was very needed in the TPT industry in Indonesia to maintain its existence.

This study used estimates with the CobbDouglas model in log form to get the TFP value. The estimation used the panel method with Eviews 10. In the panel method, there were 3 models namely pool least square (PLS), fixed effect model (FEM), and random effect model (REM). Based on the Chow Test, the Chi Square Statistic value (120.078385)> Chi Square table (44.98534), the test results rejected Ho and accepted Ha so that the Fixed Effect Model was the right model to be used in panel data regression.Based on the Hausman Test, the Chi Square Statistic value (5.863462) < Chi Square table (12.59), the test results accepted Ho then Random Effect Model was the right model to be used in panel data regression.

This study was a short panel (time-series 8 ) with cross-sections 40 . In this case statistical inference depends on the cross unit being observed, then the study used the Random Effect Model.

The estimation results used the REM model and give results: Capital variables (K), labor (L), raw materials (M), energy (E) statistically significant affected the output at the level $\alpha=5$ percent. CobbDouglas estimation models with logs to obtain TFP values, were obtained;

$y_{i t}=1,4338+0,1165 l_{i t}+0,2360 k_{i t}+0,3572 m_{i t}+$ $0,3118 e_{i t}$ 


\section{$R^{2}=0,8128$ dan $F$-statistik $=341,8659$}

The estimation results of the Cobb-Douglas model showed a positive relationship and statistically significant of the variables $\mathrm{K}, \mathrm{L}, \mathrm{M}$ and $\mathrm{E}$. These results indicated that the output of the TPT industry was affected by capital, labor, raw materials and energy. The capital coefficient indicated the degree of elasticity of capital, labor, raw materials and energy. When seen from the coefficient that was $<1$, mean inelastic, the increase in output was smaller than the increase in inputs used in the production process.

When seen from each TPT company in Indonesia, the panel method provided the results of intercepts of each TPT company obtained from different intercepts + crossid effects.

TFP measures the residual growth in total output of a company, which cannot be explained by the accumulation of inputs such as capital, labor, raw materials and energy as factors of production. The increase in TFP reflect more efficient use of inputs, and TFP was often used as a measure of long-term technological change or dynamism caused by factors such as technical innovation. TFP cannot be measured directly. On the contrary, residue was TFP which contributed to the effect on total output that was not caused by input.

From estimation results obtained constant and TPT company residues that show different results. The graph of constant and residualof the TPT companies have been arranged according to the largest to the smallest values. The largest constant value of TPT companieswas the company with KBLI 141 (PSID 54630) while the company with the smallest constant value was KBLI 141 (PSID13903). This constant value was in line with the residual value where the smaller the constant value was followed by the smaller and even negative residual value.

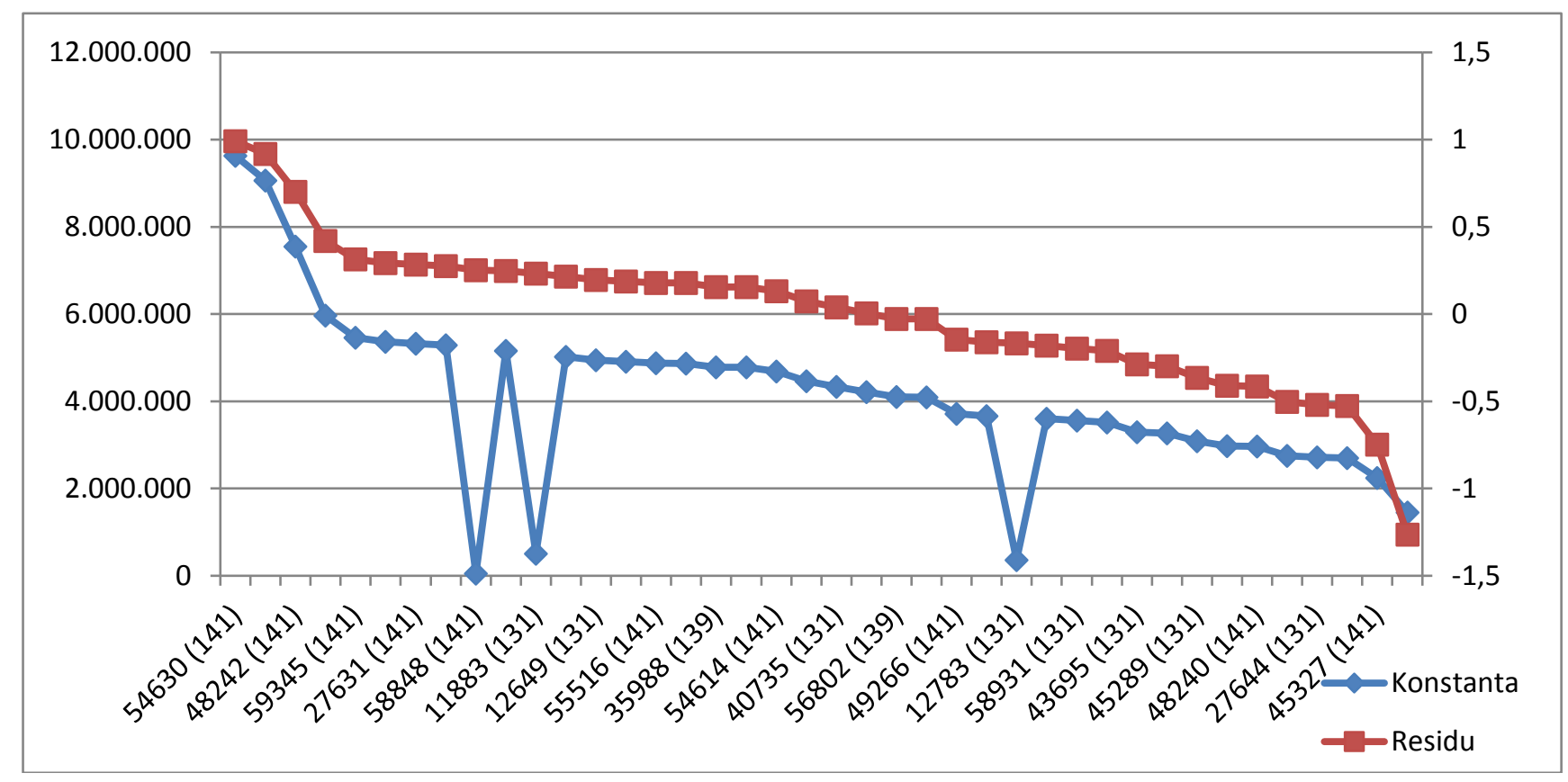

Graph 1. Graph for Constant and Residue of Company TPT

The results of the estimation showed that coefficients of capital, labor, raw materials and energy were positive and significant whichexplaining that production inputs increase TFP productivity. Things that cannot be explained in production input were related to productivity and can be explained by the amount of residue. Furthermore, industries may differ in productivity for other reasons, including business scale, technology, skill levels of the labour.
TPT in Indonesia was technically and structurally divided into three integrated industrial sectors from upstream to downstream, such as:

a. Upstream Industry Sector was an industry that produce fiber (natural fiber and or synthetic), the process of spinning into yarn. The industry was capital intensive, full automatic, large-scale, the amount of labourwas relatively small and the productivity of the labour was large. 
b. The industrial sector (midstream), including the process of weaving yarn into sheet cloth, weaving and knitting, dyeing and finishing and printing into finished cloth. The nature of the industry was semicapital intensive with medium and modern technology with a large amount oflabour.

c. Downstream Industry Sector was a garment industry and the process was to produce readymade garments. This TPT sub-sector was the subsector that absorbs the most labor and laborintensive industry.

PSID 54630 industry sub-sector (KBLI 141) was a fabric industry included in the intermediate industry group which has a large TFP value. While the industry sub-sector with PSID 12138 was an upstream industry group.

Upstream industry was an industry with capital intensive, full automatic, large scale, relatively small amount of labour and large labour productivity which should have a better level of efficiency. But in the upstream industry sub-sector group, it used imported raw material which was quite large about (90\%) with old machine age, this affected the TFP value.

TPT in Indonesia was technically and structurally an integrated industry from upstream to downstream. Upstream industry output was used as intermediate industry input, so the availability of raw materials was obtained from within the country.

The fabric industry sub-sector included in the intermediate industry with its semi-capital intensive industry with medium and modern technology with a large amount of labour which provided a large TFP result that reflects more efficient use of inputs.

\section{REFERENCES:}

[1] Baltagi, B.H., 2001,Econometric Analysis of Panel Data, John Wiley and Sons, New York.

[2] Diewert, W.E. And Nakamura, A.O., 2002, "The Measurement Of Aggregate Total Factor Productivity Growth", Elsevier Science Handbook of Econometrics, Volume 6, edited by J. J. Heckman and E. E. Leamer. University of Chicago, Hal 1-65
TFP calculation Cobb-Douglas approach used panel data regression, where the regression results obtained the residual value which became the TFP growth value approach. Residues explain the growth of productivity which cannot be shown by the input coefficients of capital, labour, raw materials and energy. This explained that productivity growth depends on inputs as well as on innovation parameters. Some observers conclude that bias in technical change translates into measurement bias in residuals.

\section{CONCLUSION}

The TPT industry was a labor intensive industry or absorbs the most labor. Most of the TPT industry has positive TFP results that reflect a good level of efficiency. In addition, the TPT industry also has the integrity between the downstream industry and the upstream industry. Some of the obstacles in the textile industry in Indonesia include the high dependence of the Indonesian TPT industry on imported raw fiber materials $(90 \%)$. This situation will adversely affect when there was a fluctuation in world cotton prices and supply. Most of the age of the machines used by the TPT industry was old, this affected the TFP value. Dependence on imported raw materials needs to be reduced by increasing domestic production. The steps that can be taken are diversification efforts from other materials, especially those originating from within the country.

The use of technology in Indonesia in the industry sector has not shown a high increase as seen by the relatively small technological growth. The government can make policies to accelerate technology transfer both from those that have been patented in Indonesia and from abroad.

[3] Griliches. 1967, "The Explanation of Productivity Change," Review of Economic Studies, 34(3), Jul, pp.

[4] Gujarati, Damodar N. And Porter, Dawn C., 2009,Basic Econometrics, Fifth Edition. New York; Mc Graw-Hill..

[5] Hulten, C. R. (1992), "Growth Accounting When Technical Change Is Embodied in Capital,"

[6] American Economic Review 82 (4): 964980. 
[7] Hulten, R Charles., 2001, "Total Factor Productivity A Short Biography", National Bureau of Economic Researh, 1-35.

[8] Wooldridge, J. 2013, Econometric Analysis of Cross Section and Panel Data, MIT Press, Cambridge MA.

[9] Direktorat Evaluasi Kinerja Pembangunan Sektoral Kementerian PPN/Bappenas , 2010, "Perubahan Produktivitas Industri Mnufaktur di Indonesia; dan Faktor-Faktor yang mempengaruhinya. Analisis Panel Data 2000 - 2007.

[10] Battese, G.E. 1992. Frontier production functions and technical efficiency: a survey of empirical applications in agricultural economics. Agricultural
Economics, Elsevier Science Publishers B.V.. Amsterdam. Vol:7. Hal: 185-208

[11] Porter Michael, E., 2000," Location, Competition, and Economic Development: LocalClusters in a Global Economy", Economic Development Quarterly, Published by:Sage Publications.Vol. 14 Issue 1, p15, 20p.

[12] M.H.Lies, 2015," Dampak Spillovers Penanaman Modal Asing (PMA) Terhadap Produktivitas Industri Manufaktur Di Indonesia Tahun 2000 2010, Disertasi Fakultas Ekonomika Dan Bisnis Universitas Gajah Mada Yogyakarta

Creative Commons Attribution License 4.0 (Attribution 4.0 International, CC BY 4.0)

This article is published under the terms of the Creative Commons Attribution License 4.0

https://creativecommons.org/licenses/by/4.0/deed.en_US 